\title{
Assessment of Genotoxic and Cytogenetic Effects of Aflatoxin B1 in Mouse Bone Marrow Cells
}

\author{
Awad A. Algarni* \\ Department of Biology, College of Science and Arts, Albaha University, Baljurashi, \\ Saudi Arabia \\ *Corresponding author
}

\section{A B S T R A C T}

\begin{tabular}{|l|}
\hline K e y w o r d s \\
$\begin{array}{l}\text { Aflatoxin B1, Mycotoxin, } \\
\text { Genotoxicity, } \\
\text { Mutagenicity, DNA } \\
\text { Damage, Chromosome } \\
\text { Aberrations, Mitotic } \\
\text { index, Micronuclei } \\
\text { induction }\end{array}$ \\
\hline Article Info \\
\hline $\begin{array}{l}\text { Accepted: } \\
10 \text { March } 2018 \\
\text { Available Online: } \\
10 \text { April } 2018\end{array}$ \\
\hline
\end{tabular}

\section{Keywords}

Genotoxicity,

Mutagenicity, DNA

Damage, Chromosome

Aberrations, Mitotic

induction

\section{Introduction}

Aflatoxins refer to a cluster of difuranocoumarin compounds which are mainly produced by Aspergillus flavus and Aspergillus parasiticus fungi species (Steyn, 1995). These chemicals can contaminate human consumption crops such as corn, peanut, sorghum, rice, wheat, and nut (Cleveland et al., 2003). The most common aflatoxins are B1, B2, G1 and G2 which are naturally present in many food products and affect several organ systems simultaneously. This produces a cascade of responses in the

\begin{abstract}
Aflatoxin B1 (AFB1) is a widespread mycotoxin produced by toxicogenic Aspergillus species. AFB1 has been reported to cause harmful health effects, such as cancers and abnormal development and reproduction, in animals and humans. The current study was carried out to evaluate the genotoxic aspects of Aflatoxin B1 in the bone marrow cells obtained from Swiss albino mice, using chromosomal aberrations (CA), mitotic index (MI), and micronuclei (MN) formation as toxicological end points. Four groups of four days with, weighing approximately $20-25 \mathrm{~g}$, were orally administered once a day for 30 of four animals orally administered with Deionized water. AFB1 exposure significantly increased the number of CA and the frequency of micronucleated cells and decreased the mitotic in treated groups when compared with the control group. This significant increase in CAs as well as micronuclei formation induced by AFB1 may be attributed to the fact that AFB1 can induce genotoxicity through DNA damage. Thus, the present study indicates that AFB1 was genotoxic in vivo in bone-marrow cells of mice.
\end{abstract}

affected organism (Ferenčík and Ebringer, 2003; Herzallah, 2013). Human beings are mainly exposed to aflatoxins through secondary sources after the consumption of animal products that had previously ingested contaminated feed. Aflatoxins are highly lipophilic and are therefore quickly absorbed via the alimentary canal. Moreover, they can enter the bloodstream directly through inhalation (Bbosa et al., 2013). It is estimated that approximately 4.5 billion people across the globe, especially in low-income countries are exposed to food that is contaminated with aflatoxin (Williams et al., 2004). Among the 
major aflatoxins, aflatoxin B1 (AFB1) is the most widely known carcinogen. Continued exposure to AFB1 results in stunted growth, mutagenicity, genotoxicity, and immunosuppression. It also caused an increasing hepatocellular carcinoma (HCC) incidence in humans and animals (Theumer et al., 2010; Abbes et al., 2010; Sun et al., 2011). Aflatoxin B1 works synergistically with some human health factors such as hepatitis B virus infection, nutritional status, sex, age and the amount of AFs exposure to initiate the development of cancer (Qureshi et al., 2014; Wild and Montesano, 2009). Other complications that result from AFB1 include the induction of a variety of biological activities like acute toxicity, teratogenicity and membrane damage which happens due to increased peroxidation of lipid and the generation of free radicals (Abdel-Wahhab et al., 2012; Mary et al., 2012).

There is an association between carcinogenicity of AFB1 and the alteration of several p53- target gene expressions and mutations, mainly the p53 codon 249 hotspot mutations (Josse et al., 2012). Several reports have shown the detrimental effects of AFB1 on the liver (Hassan et al., 2015), testis, epididymis (Agnes and Akbarsha, 2001; Hamzawy et al., 2012), Kidney (Abdel-Hamid and Firgany Ael, 2015; Arora et al., 1978), Heart (Abdulmajeed, 2011; Mohamed and Metwally, 2009), ovary (Ibeh et al., 2000), and the brain (Bahey et al., 2015). According to evidence from IARC (International Agency for Research on Cancer), AFB1 is a Group 1 human carcinogen with no intended safe dose (Babu et al., 2014). Cytogenetic assays, such a chromosome aberrations and micronucleus assay are detectable by cytogenetic analysis of chromosome in metaphase. These cytogenetic endpoints are widely used to assess the mutagenic and carcinogenic potential of chemical compounds (Albertini et al., 2000). The main objective of this study was to determine the genotoxic effect of AFB1 in the bone marrow cells of Swiss albino mice using chromosomal aberrations, mitotic index and micronuclei formation as the toxicological endpoints.

\section{Materials and Methods}

\section{Chemicals}

All the chemicals used, including AFB1, were purchased from Sigma Chemical Co., St. Louis, MO.

\section{Animals}

Swiss albino mice, male and female of 10-12 weeks of age, and weighing 20-25 g were used in this study. Mice were housed in individual plastic cages under standard laboratory conditions at a temperature of 22.1 $\pm 0.8{ }^{\circ} \mathrm{C}, 36.3 \pm 3.3 \%$ humidity and $12 / 12 \mathrm{~h}$ light/dark photoperiod, with ad libitum access to food (commercial mouse pellets) and water throughout the experiments.

\section{Doses}

Groups of four mice each were treated with five different AFB1 dose levels. AFB1 were diluted with deionized water and orally administered using feeding needles to the mice at the doses of $1,2,4,8$ and $16 \mathrm{mg} / \mathrm{kg} \mathrm{BW}$. One dose per $24 \mathrm{~h}$ given for 30 days. Deionized water was used as negative control. Negative control group was administered in the same manner as in the treatment groups.

\section{Chromosome aberration assay}

Cytogenetic analysis was performed on bone marrow cells according to the recommendations of Preston et al., (1987), with slight modifications. Experimental animals were intraperitonally injected with colchicine (4 $\mathrm{mg} / \mathrm{kg}) \quad 1.5$ hours prior to 
sacrifice. Animals were sacrificed by cervical dislocation 24 hours after the last dose. Both femora were dissected and cleaned of any adhering muscle. Bone marrow cells were collected from both femora by flushing in warm $\mathrm{KCl}\left(0.075 \mathrm{M}\right.$, at $\left.37^{\circ} \mathrm{C}\right)$ and incubated at $37^{\circ} \mathrm{C}$ for $25 \mathrm{~min}$. Following incubation, the material was centrifuged at $2000 \mathrm{rpm}$ for 5 min. The supernatant was decanted and the cell pellet was fixed in aceto-methanol (acetic acid: methanol, 1:3, v/v). Centrifugation and fixation was repeated twice with an interval of $30 \mathrm{~min}$. Cells were then resuspended in a small volume of fixative, dropped onto chilled slides, and allowed to dry. The slides were stained the following day with freshly prepared 2\% Giemsa stain for 3-5 min, and washed in distilled water to remove excess stain. A total of 200 well spread metaphase cells were scored for CAs at a magnification of $1000 \times(100 \times 10)$ for each group.

\section{Mitotic index determination}

The MI (number of dividing cells/total number of cells $\times 100$ ) was used to determine the rate of cell division. The slides prepared for assessment of CAs were also used for calculating the MI. Randomly selected views on the slides were monitored to determine the number of dividing cells (metaphase stage) and the total number of cells. At least 1000 cells were examined in each preparation.

\section{Micronucleus assay}

Mice were sacrificed by cervical dislocation $24 \mathrm{~h}$ after the last treatment. The frequency of micronucleated cells in femoral bone marrow was evaluated according to the procedure of Schmid et al., (1976), with slight modifications as reported by Agarwal \& Chauhan (1993). The bone marrow was flushed out from both femora using $2 \mathrm{~mL}$ of Fetal Calf Serum and Hanks Balanced Salt Solution (3:1), and centrifuged at 2000x $g$ for
10 min. The supernatant was discarded. Evenly spread bone marrow smears were stained using the May-Grunwald and Giemsa protocol (Zaizuhana et al., 2006). A total of 4000 cells/treatment were scored on coded slides to evaluate the frequency of micronucleated cells in bone marrow under an Olympus microscope.

\section{Statistical analysis}

Data were analyzed by one-way analysis of variance (ANOVA) followed by two-tailed ttest when the ANOVA test yielded statistical differences $(p<0.05$ or 0.01$)$. A value of $p<$ 0.05 was used as the criterion for statistical significance. All data were expressed as the mean $\pm \mathrm{SD}$.

\section{Results and Discussion}

\section{Chromosomal aberrations}

Aflatoxin B1 induced a statistically significant increase in CAs in metaphase bone marrow cells. Table 1 shows the mean frequency of cells with aberrations (as percentages) calculated for each dose with four animals/dose. Different types of aberrations, i.e., stickiness, chromatid gap, fragment, Robertsonian Centric Fusion (RFC), and polyploidy were observed. The mean percentages of the induced CAs were $4+0.82$ $\%, 6 \pm 0.8 \%, 11 \pm 1.7 \%, 19 \pm 1.3 \%, 25 \pm$ $2.1 \%$ and $40 \pm 2.2 \%$ at AFB 1 doses of $0,1,2$, 4, 8 and $16 \mathrm{mg} / \mathrm{kg} \mathrm{BW}$, respectively. Aflatoxin B1 showed a concentration-dependent increase in the frequency of CAs (Figure 1). At high concentrations of AFB1 $(16 \mathrm{mg} / \mathrm{mL})$, sticky chromosomes and gaps were the most common CAs observed.

\section{Mitotic Index}

The MI was used to determine the rate of cell division in the bone marrow cells of mice. 
Table.1 Percentage of mitotic index (MI) and chromosomal aberrations (CAs) in mice bone marrow after treatment with AFB1

\begin{tabular}{|c|c|c|c|c|c|c|c|}
\hline $\begin{array}{c}\text { Dose } \\
(\mathrm{mg} / \mathrm{kg})\end{array}$ & MI \pm SD & \multicolumn{5}{|c|}{ \% Chromosomal aberration (CAs) } & $\begin{array}{c}\text { \% Aberration } \\
\text { (mean } \pm \text { SD) }\end{array}$ \\
\hline 1 & $\begin{array}{c}4.2 \pm \\
0.69\end{array}$ & 3 & 2 & 1 & 0 & 0 & $6 \pm 0.8$ \\
\hline 2 & $\begin{array}{c}2.9 \pm \\
0.68\end{array}$ & 5 & 2 & 2 & 2 & 0 & $11 \pm 1.7$ \\
\hline 4 & $\begin{array}{c}2.1 \pm \\
0.50\end{array}$ & 8 & 2 & 3 & 4 & 2 & $19 \pm 1.3$ \\
\hline 8 & $\begin{array}{c}1.1 \pm \\
0.38\end{array}$ & 10 & 4 & 5 & 2 & 4 & $25 \pm 2.1$ \\
\hline 16 & $0.7 \pm 0.4$ & 11 & 8 & 10 & 5 & 6 & $40 \pm 2.2$ \\
\hline N.C & $8.2 \pm$ & 2 & 1 & 1 & 0 & 0 & $4 \pm 0.82$ \\
\hline
\end{tabular}

$\mathrm{NC}=$ Negative Control

*Robertosonian Centric Fusion (RCF).

Table.2 Percentage of micronucleated cells in mice bone marrow after AFB1 treatment

\begin{tabular}{|c|c|c|c|}
\hline $\begin{array}{c}\text { Dose } \\
(\mathbf{m g} / \mathrm{kg})\end{array}$ & $\begin{array}{c}\text { No. of cells } \\
\text { counted }\end{array}$ & $\begin{array}{c}\text { No. of } \\
\text { micronuclei }\end{array}$ & $\begin{array}{c}\text { \% micronuclei } \\
(\text { mean } \pm \text { SD) }\end{array}$ \\
\hline $\mathbf{N C}$ & 4000 & 11 & $2.8 \pm \mathbf{0 . 9 5}$ \\
\hline 1 & 4000 & 17 & $4.3 \pm 1.3$ \\
\hline 2 & 4000 & 29 & $7.3 \pm 1.7$ \\
\hline 4 & 4000 & 42 & $10.5 \pm 1.9$ \\
\hline 8 & 4000 & 56 & $14 \pm 1.6$ \\
\hline 16 & 4000 & 102 & $25.5 \pm 2.3$ \\
\hline
\end{tabular}

Fig.1 Effects of AFB1 on the frequency of chromosomal aberrations

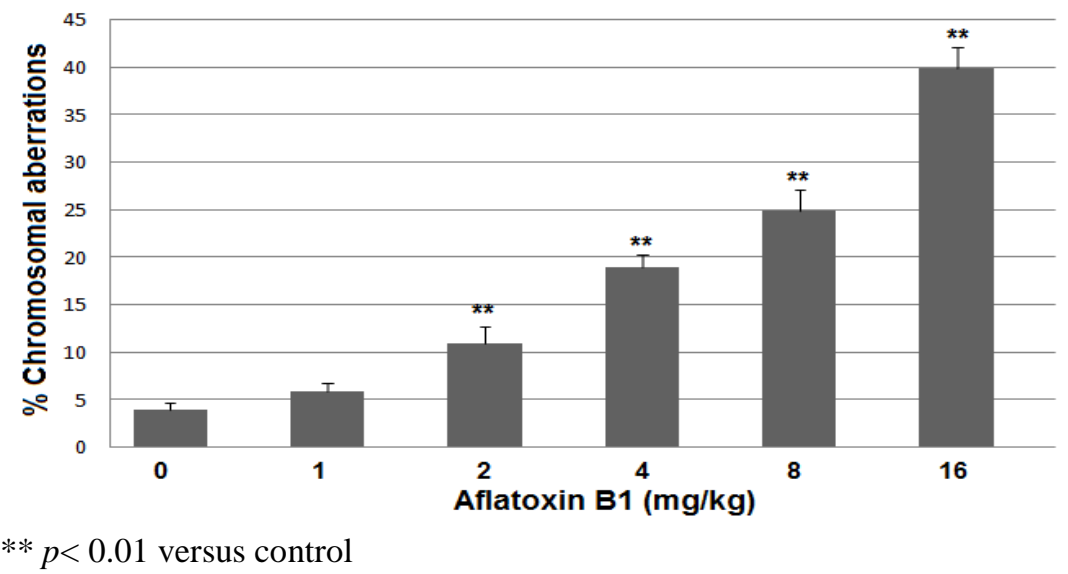


Fig.2 Effect of AFB1 on the percent mitotic index

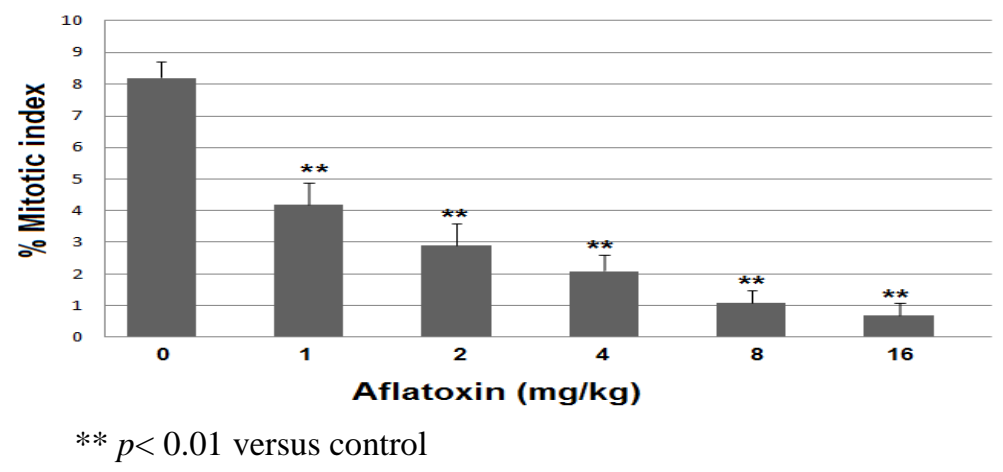

Fig.3 Effect of AFB1 on the percent micronuclei induction

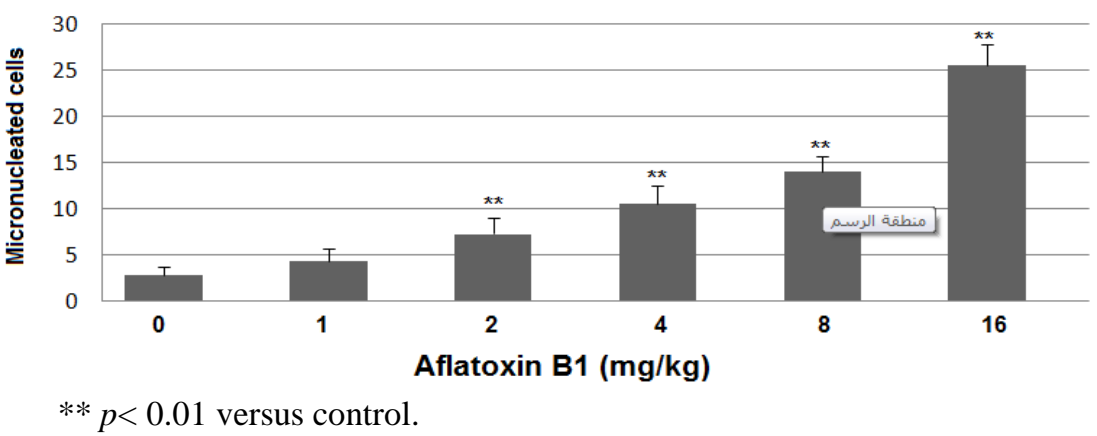

Mitotic Index depression was observed, and it was found to be dose-dependent (Figure 2). Mean percentages of MI were $8.2 \%, 4.2 \%$, $2.9 \%, 2.1 \%, 1.1 \%$ and 0.7 for the doses 0,1 , 2, 4, 8, and $16 \mathrm{mg} / \mathrm{Kg} \mathrm{BW}$ of AFB1 (Table 1).

\section{Micronuclei induction}

The frequency of micronuclei in bone marrow cells after treatment with AFB1 are given in Table 2. Aflatoxin B1 induced a dosedependent increase in micronuclei frequency, which was significantly different $(p<0.01)$ from that in the negative control (Figure 3). The mean frequencies of micronucleated cells $2.8 \pm 0.95,4.3 \pm 1.3,7.3 \pm 1.70,10.5 \pm 1.90$, $14 \pm 1.6,25.5 \pm 2.3 \%$ at AFB1 doses of 0,1 , $2,4,8$ and $16 \mathrm{mg} / \mathrm{kg} \mathrm{BW}$, respectively.

A detailed assessment of the genotoxic potential of AFB1 in exposed mice bone marrow was carried in this investigation. The study used CAs, MI, and micronucleus assay as toxicological endpoints. The findings of the evaluation revealed a significant rise in cytogenetic damage in the bone marrow cells associated with exposure to AFB1. The comparative results of the AFB 1 and control group showed significant differences in context of the CAs percentages in the bone marrow of Swiss albino mice. We have also measures a significant decline in mean of MI values in AFB1-tretaed groups relative to the control groups. Additionally, micronucleus assay measurements depicted an AFB1 induced rise in mean percentages of the micronucleated cells. The extensive use of chromosomal aberrations can be found mainly for evaluating the genotoxicity in human subjects (Kao-Shan et al., 1987). Moreover, there are numerous evidences reported in past studies in which researchers have shown a 
strong correlation between induction of CAs and the risk of cancer (Norppa et al., 2006; Ray et al., 2001). The results of these studies showed that AFB1 induced different type of CA such as stickiness, chromatid gap, fragment, Robertsonian Centric Fusion (RFC) and polyploidy. The lowest dose of $(1 \mathrm{mg} / \mathrm{kg})$ of AFB1 could induce any significant increase in the frequency of CA. However. The doses 2, 4, 8, and $16 \mathrm{mg} / \mathrm{kg}$ of AFB1 induced a significant increase in the frequency of CA. The results are corresponding with the previous studies indicating rising frequency of CA succeeding AFB1 treatment in vivo (Ito el al., 1989; Adgigitov et al., 1984; Anwar et al., 1994; Krishnamurthy and Neelaram, 1986) and in vitro (Batt et al., 1980; Fadl-Allah et al., 2011; Werner et al., 1992). The production of $\mathrm{CA}$ is a complicated cellular procedure. For this reason, researchers have failed to understand completely the mechanisms of chromosome breakage and rejoining (Palitti et al., 1998; Savage et al., 1988). The existing theories have provided the processes leading to the production of CA. It can result from direct DNA rupture, reproduction on a broken DNA pattern, inhibition of DNA mixture. Topoisomerase II inhibition is also among one of such process (Albertini et al., 2000). However, under in vivo conditions, the genotoxicity assessment and in particular, the clastogenic potential of an agent is evaluated using the CA assay (Preston et al., 1987). MI rate was the second parameter utilized in the current investigation for determining the cytogenetic potential of AFB1. The MI is defined as the proportion of cells undergoing mitosis (cell division) compared to the total number of cells. Hence, the MI is critical to determine the rate of cell division (Moor et al., 2011). We have depicted a significant decrease in the mean MI values in AFB1 treated groups relative to the control groups. The centric fragments or laggards being omitted from the nucleus proper during mitosis further lead to development of micronuclei. Such a rise in micronuclei is also suggestive of the abilities of test chemicals in producing different types of CAs (Ma et al., 1995). The results from this study showed a statistically significant difference in the frequencies of micronuclei induction in mice bone marrow exposed to AFB1 when compared to the control. These results were in agreement with the studies that have shown increased micronuclei formation in treated cells exposed to AFB1 (Madrigal-Santilla'n et al., 2006; Ezekiel et al., 2011; Corcuera et al., 2015). In conclusion, our data suggest that AFB1 induces CAs and the formation of micronuclei in the bone marrow cells of mice. The repression in MI indicates the potential for AFB1 to induce growth arrest or to inhibit cell growth. These findings demonstrate that AFB1 has a strong clastogenic/genotoxic potential.

\section{References}

Abbes, S., Ben Salah-Abbes, J., AbdelWahhab, M.A., Ouslati, R. (2010) Immunotoxicological and biochemical effects of aflatoxins in rats prevented by Tunisian montmorillonite with reference to HSCAS. Immunopharmacol. Immunotoxicol., 32 (3), 514-522.

Abdel-Hamid, A., Firgany Ael, D. (2015) Vitamin E supplementation ameliorates aflatoxin B1-induced nephrotoxicity in rats. Acta. Histochem., 117, 767-779.

Abdel-Wahhab, A., Ibrahim, A., El-Nekeety, A., Hassan, S., Mohamed, A. (2012) Panax ginseng C.A. Meyer extract counteracts the oxidative stress in rats fed multi-mycotoxins-contaminated diet. Comu. Sci., 3 (3), 143-153.

Abdulmajeed, A. (2011) Therapeutic ability of some plant extracts on aflatoxin B1 induced renal and cardiac damage. Arab. J. Chem., 4, 1-10. 
Adgigitov, I., Kosichenko, P., Popandopulo, G. Gubeladze, A. Djemilev, A. (1984) Frequency of chromosome aberrations in bone marrow of monkeys and their F1 after aflatoxin B1 injection. Exp. Pathol., 26, 163-9.

Agarwal, K., and Chauhan, S. (1993) An improved chemical substitute for fetal calf serum for the micronucleus test. Biotechnol. Histochem., 68, 187-188.

Agnes, F., Akbarsha, A. (2001) Pale vacuolated epithelial cells in epididymis of aflatoxin-treated mice. Reproduction, 122, 629-641.

Albertini, J., Anderson, D., Douglas, R., Hagmar, L., Hemminki, K., Merlo, F., Natarajan, T., Norppa, H., Shuker, E., Tice, R., Waters, D., Aitio, A. (2000) IPCS guidelines for the monitoring of genotoxic effects of carcinogens in humans. International Programme on Chemical Safety. Mutat. Res., 463, 111-172.

Anwar, W., Khalil, M., Wild, C. (1994) Micronuclei, chromosomal aberrations and aflatoxin-albumin adducts in experimental animals after exposure to aflatoxin B1. Mutat. Res., 322, 61-67.

Arora, G., Appelgren, E., Bergman, A. (1978) Distribution of [14C]-labelled aflatoxin B1 in mice. Acta Pharmacol. Toxicol., 43, 273-279.

Babu, D., Muriana, M. (2014) Sensitive quantification of aflatoxin B1 in animal feeds, corn feed grain, and yellow corn meal using immunomagnetic beadbased recovery and real-time immunoquantitative -PCR. Toxins, 12, 3223-3237.

Bahey, G., Abd Elaziz, O., Gadalla, K. (2015) Toxic effect of aflatoxin B1 and the role of recovery on the rat cerebral cortex and hippocampus. Tissue and Cell, 47, 559-566.

Batt, R., Hsueh, L., Chen, H., Huang, C. (1980) Sister chromatid exchanges and chromosome aberrations in V79 cells induced by aflatoxin B1, B2, G1 and G2 with or without metabolic activation. Carcinogenesis, 9, 759-63.

Bbosa, S., Kitya, D., Lubega, A., OgwalOkeng, J., Anokbonggo, W., Kyegombe, B. (2013) Review of the biological and health effects of aflatoxins on body organs and body systems. Aflatoxins-recent advances and future prospects. Intechopen. Publ., 12, 239-265

Cleveland, E., Dowd, F., Desjardins, E., Bhatnagar, D., Cotty, J. (2003) United States Department of Agriculture Agricultural Research Service, Research on pre-harvest prevention of mycotoxins and mycotoxigenic fungi in US crops. Pest Manag. Sci., 59, 629642.

Corcuera, A., Vettorazzi, L., Arbillag, N., Pérez, A., Gil, A., Azqueta, A., González-Peñas, A, López de Cerain, A. (2015) Genotoxicity of Aflatoxin B1 and Ochratoxin A after simultaneous application of the in vivo micronucleus and comet assay. Food Chem. Toxicol., 76, 116-124.

Ezekiel, N., Alabi, A., Anokwuru, P., Oginni, O. (2011) Studies on dietary aflatoxininduced genotoxicity using two in vivo bioassays. Archives of Applied Science Research, 3 (2), 97-106.

Fadl-Allah, M., Mahmoud, H., Abd El-Twab, H., Helmey, K. (2011) Aflatoxin B1 induces chromosomal aberrations and $5 \mathrm{~S}$ rDNA alterations in durum wheat. J. Assoc. Arab. Univ. Basic Appl. Sci., 10, 8-14.

Ferenčík, M., Ebringer, L. (2003) Modulatory effects of selenium and zinc on the immune system. Folia microbiologica, 48, 417-26.

Hamzawy, A., El-Denshary, S., Hassan, S., Mannaa, A., Abdel-Wahhab, A. (2012) Antioxidant and hepatorenoprotective 
effect of thyme vulgaris extract in rats during aflatoxicosis. Glob. J. Pharmacol., 6 (2), 106-117.

Hassan, M., Abdel-Azeim, H., El-Nekeety, A., Abdel-Wahhab, A. (2015) Panax ginseng extract modulates oxidative stress, DNA fragmentation and upregulate gene expression in rats sub chronically treated with aflatoxin B1 and fumonisin B1. Cytotechnology, 67, 861-871.

Herzallah, M. (2013) Aflatoxin B1 residues in eggs and flesh of laying hens fed Aflatoxin B1 contaminated diet. Am. J. Agr. Bio. Sci., 8,156- 61.

Ibeh, N., Saxena, K., Uraih, N. (2000) Toxicity of aflatoxin: effects on spermatozoa, oocytes, and in vitro fertilization. J. Environ. Pathol. Toxicol. Oncol., 19, 357-361.

Ito, Y., Ohnishi, S., Fujiie, K. (1989) Chromosome aberrations induced by aflatoxin B1 in rat bone marrow cells in vivo and their suppression by green tea. Mutat. Res., 222, 253-261.

Josse, R., Dumont, J., Fautre, A., Robin, M., Guillouzo, A. (2012) Identification of early target genes of aflatoxin B1 in human hepatocytes, inter-individual variability and comparison with other genotoxic compounds. Toxicol. Appl. Pharmacol., 258, 176-187.

Kao-Shan, S., Fine, L., Whang-Peng, J., Lee, C., Chabner, A. (1987) Increased fragile sites and sister chromatid exchanges in bone marrow and peripheral blood of young cigarette smokers. Cancer Res. 47(23), 6278-6282.

Krishnamurthy, B., Neelaram, S. (1986) Effect of dietary fat on aflatoxin B1 induced chromosomal aberrations in mice. Tox. Let., 31(3), 229-234.

Ma, H., Xu, Z., Xu, C., McConnell, H., Rabago, V., Arreola, A., Zhang, H. (1995) The improved Allium / Vicia root tip micronucleus assay for clastogenicity of environmental pollutants. Mutat. Res. 334, 185-195.

Madrigal- Santillán, E., Madrigal-Bujaidar, E., Márquez-Márquez, R., Reyes, R. (2006) Antigenotoxic effect of Saccharomyces cerevisiae on the damage produced in mice fed with aflatoxin B (1) contaminated corn. Food Chem. Toxicol., 44, 2058-2063.

Mary, S., Theumer, G., Arias, L., Rubinstein, R. (2012) Reactive oxygen species sources and biomolecular oxidative damage induced by aflatoxin B1 and fumonisin B1 in rat spleen mononuclear cells. Toxicology, 302, 299-307.

Mohamed, M., Metwally, S. (2009) Antiaflatoxigenic activities of some plant aqueous extracts against Aflatoxin-B1 induced renal and cardiac damage. J. Pharmacol. Toxicol. 4, 1-16

Moor, D., Patlolla, K., Tchounwou, B., (2011) Cytogenetic evaluation of malathioninduced toxicity in Sprague-Dawley rats. Mutat. Res., 725, 78-82.

Norppa, H., Bonassi, S., Hansteen, L., Hagmar, L., Strömberg, U., Rössner, P. (2006) Chromosomal aberrations and SCEs as biomarkers of cancer risk. Mutat. Res. 600(1-2), 37-45.

Palitti, F. (1998) Mechanisms of the origin of chromosomal aberrations. Mutat. Res. 404,133-137.

Preston, J., Dean, J., Galloway, S., Holden, H., McFee, F., Shelby, M. (1987) Mammalian in vivo cytogenetic assays: analysis of chromosome aberrations in bone marrow cells. Mutat. Res., 189, $157-165$

Qureshi, H., Ali, S., Iqbal, M., Siddiqui, A., Khan, A., Hamid, S. (2014) Aflatoxins and hepatitis B, C viral associated hepatocarcinogenesis. J. Cell Sci. Ther., 5 (179)

Ray, N., Shahid, M., Husain, A. (2001) Status of chromosome breaks and gaps in 
breast cancer. A followup study. Cancer Genet. Cytogenet. 130(2), 155-9.

Savage, P., Keefe, J., Mounce, W., Heaton, K., Lewis, A., Burcar, J. (1988) Chronic neurological sequel of acute organophosphate pesticide poisoning, Arch. Environ. Health, 43, 38-45.

Steyn, S. (1995) Mycotoxins, general view, chemistry and structure. Toxicol. Lett., 82 (3), 843-851.

Sun, G., Wang, S., Hu, X., Su, J., Zhang, Y., Xie, Y., Zhang, H., Tang, L., Wang, S.(2011) Co-contamination of aflatoxin B1 and fumonisin B1 in food and human dietary exposure in three areas of China. Food Addit. Contam. A. Chem. Anal. Control Expo. Risk Assess., 28 (4), 461-470.

Theumer, G., Canepa, C., Lopez, G., Mary, S., Dambolena, S., Rubinstein, R. (2010) Subchronic mycotoxicoses in Wistar rats: assessment of the in vivo and in vitro genotoxicity induced by fumonisins and aflatoxin B1, and oxidative stress biomarkers status. Toxicology, 268, 104-110.

Werner, E., Kota, S., Gill, S., Endo, R. (1992) Distribution of telomeric repeats and their role on the healing of broken chromosome ends in wheat. Genom, 35, 844-848.

Wild, C., Montesano, R. (2009) A model of interaction: aflatoxins and hepatitis viruses in liver cancer etiology and prevention. Cancer Lett., 286 (1), 22-28.

Williams, H., Phillips, D., Jolly, E., Stiles, M., Aggarwal, D. (2004) Human aflatoxicosis in developing countries: a review of toxicology, exposure, potential health consequences, and interventions. Am. J. Clin. Nutr., 80, 1106-1122.

Zaizuhana, S., Puteri, J., Noor, M.B., Noralashikin, Y., Muhammad, H., \& Rohana, A.B. (2006). The in vivo rodent micronucleus assay of Kacip Fatimah Labisia pumila extract. Tropical Biomed., 23, 214-219.

\section{How to cite this article:}

Awad A. Algarni. 2018. Assessment of Genotoxic and Cytogenetic Effects of Aflatoxin B1 in Mouse Bone Marrow Cells. Int.J.Curr.Microbiol.App.Sci. 7(04): 1265-1273. doi: https://doi.org/10.20546/ijcmas.2018.704.141 